\title{
Cyanide-insensitive Respiration of Phytopathogenic Fungi Demonstrated by Antifungal Joint Action of Respiration Inhibitors
}

\author{
Keisuke Hayashi, Masanori Watanabe, Toshinobu TanaKa and Yasuhiko Uesugi \\ Ube Research Laboratory, Ube Industries, Ltd., Tokiwadai, Ube 755, Japan
}

(Received November 6, 1995 ; Accepted July 19, 1996)

\begin{abstract}
A survey was conducted for involvement of cyanide-insensitive respiration of phytopathogenic fungi by testing a joint fungitoxic action between salicylhydroxamic acid (SHAM) as an inhibitor of the cyanide-insensitive pathway and the inhibitors of cytochrome pathway of respiratory chain such as methoxyacrylate derivatives or antimycin A. Remarkable synergism in fungitoxic action was shown in Botrytis cinerea, Monilinia fructicola and Pyricularia oryzae. The synergism may result from the induction of the alternative pathway by the latter inhibitors and the inhibition of the induced alternative pathway by SHAM. To confirm the induction of the alternative pathway, effects of SHAM on oxygen consumption by hyphal cells of three fungi were tested by pretreating with methoxyacrylate or potassium cyanide. These results confirmed the induction of cyanide-insensitive respiration by the pretreatment with methoxyacrylate or potassium cyanide as expected from the joint fungitoxic action. The synergism in fungitoxic action was also observed in Cochliobolus miyabeanus, though it was less remarkable. In Rhizoctonia solani, the synergism was observed with methoxyacrylates but hardly with antimycin A, so that cyanide-insensitive respiration was induced with the methoxyacrylates but hardly with antimycin A in Rhizoctonia solani. In Gibberella fujikuroi, Pythium sp. and Valsa ceratosperma the synergism was not necessarily clear. A phytopathogenic bacterium, Xanthomonas campestris pv. citri and a yeast, Saccharomyces cerevisiae did not show any synergism in joint antimicrobial action of the above inhibitors.
\end{abstract}

\section{INTRODUCTION}

Cytochrome pathway in respiratory chain is important for aerobic organisms, and the inhibitors of the pathway are fatal to most aerobic organisms. To some organisms, however, the inhibitors are not fatal because an alternative pathway bypassing cytochromes could be formed (Fig. 1). Phytopathogenic fungi, Ustilago maydis ${ }^{1,2)}$ Ceratocystis ulmi ${ }^{1)}$ and Fusarium lini ${ }^{3)}$ have already been reported to exhibit such an alternative pathway. Recently a methoxyacrylate analogue SSF126 was reported to induce a cyanide-insensitive pathway of respiration in Pyricularia oryzae. ${ }^{4,5)}$ It was also observed with another derivative of methoxyacrylate in Botrytis cinerea. ${ }^{6)}$ These results may explain the reason why methoxyacrylate fungicides often do not exhibit fungitoxicity in ordinary in vitro tests. At the same time, existence of the alternative pathway might be rather popular in phytopathogenic fungi than it has been reported.

In the present experiment, a survey of the alternative pathway among phytopathogenic fungi was conducted by two methods. One is the test for joint fungitoxic action between an inhibitor of alternative pathway, salicylhydroxamic acid (SHAM), and inhibitors of cytochrome pathway such as methoxyacrylate derivatives or antimycin A, using crossed paper technique. ${ }^{7,8)}$ The other is the test for oxygen consumption by the fungal cells with and without pretreatment with a methoxyacrylate or with potassium cyanide. The pretreatment was expected to inhibit the cytochrome pathway and induce the alternative pathway. These actions by the pretreatment were checked by the effects of the inhibitors on the oxygen consumption by the fungal cells.

\section{MATERIALS AND METHODS}

\section{Compounds}

A methoxyacrylate, (E)-methyl 3-methoxy-2-(O-Estyrylphenyl)acrylate (I), was chosen for the present experiment because it showed a typical joint fungitoxic action with SHAM in the preliminary tests. Another methoxyacrylate analogue, $(E)$-2-methoxyimino- $N$-meth- 


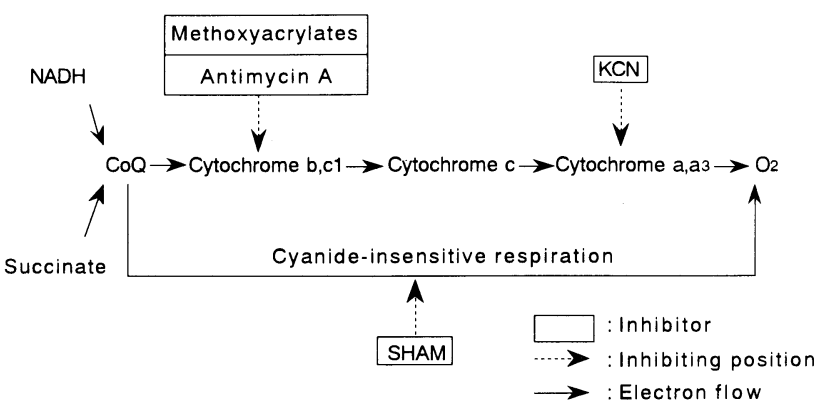

Fig. 1 Electron transfer in mitochondrial respiratory chain and the inhibitors.

CoQ : coenzyme Q.

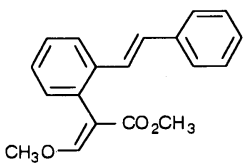

I

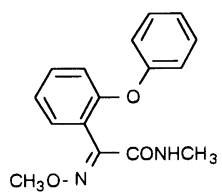

II

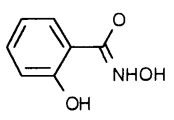

III
Fig. 2 Chemical structures of tested methoxyacrylate derivatives (I, II) and SHAM (III).

yl-2-(2-phenoxyphenyl)acetamide (SSF-126, II), was also tested. These methoxyacrylate derivatives were synthesized according to the procedure described in the respective patents. Antimycin A (Sigma Chem. Co.), SHAM (Sigma Chem. Co.) and other chemicals were commercially obtained.

\section{Test Microbes}

Test phytopathogenic fungi and other microbes and their sources are stated in Table 1. They are kept on PDA medium at $25^{\circ} \mathrm{C}$.

\section{Test for Joint Fungitoxic Action}

Crossed paper technique ${ }^{7,8)}$ was used to observe joint fungitoxic action between SHAM and inhibitors of cyto- chrome pathway such as methoxyacrylate I, its analogue II or antimycin A. Cell suspension of test microbes were obtained from conidia of $P$. oryzae produced on 7 day culture on oatmeal medium, and from conidia of Alternalia kikuchiana, B. cinerea, Cochliobolus miyabeanus, Gibberella fujikuroi, Monilinia fructicola and Valsa ceratosperma, hyphal cells of Pythium sp. and Rhizoctonia solani, and yeast cells of Saccharomyces cerevisiae and bacterial cells of Xanthomonas campestris pv. citri each produced on 7 day culture on PDA medium. The cell suspensions were added to PDA medium at about $60^{\circ} \mathrm{C}$ to make test agar plates. Strips of filter paper $(7 \times 80 \mathrm{~mm})$ were impregnated with acetone solution of test inhibitors, air-dried and placed on the test agar plates to form a cross inhibition.

\section{Test for Oxygen Consumption by Phytopathogenic Fungi}

Test fungi, B. cinerea, M. fructicola and $P$. oryzae were cultured in potato dextrose broth (PDB) for 3 days at 25 ${ }^{\circ} \mathrm{C}$ with shaking, and hyphal cells were harvested by filtration through a Buechner funnel and washed twice with distilled water. Test yeast $S$. cerevisiae were also cultured in PDB for 3 days at $25^{\circ} \mathrm{C}$ with shaking, and yeast cells were collected by centrifugation $(3000 \times g, 10$ $\mathrm{min})$ and washed twice with distilled water. The cells $(0.25 \mathrm{~g}$ fresh weight) were suspended in $5 \mathrm{ml}$ of $50 \mathrm{mM}$ phosphate buffer ( $\mathrm{pH} 6.5$ ), preincubated at $30^{\circ} \mathrm{C}$ for 15 min and incubated further with or without addition of final $10 \mu \mathrm{M}$ of methoxyacrylate I or final $1 \mathrm{mM}$ of potassium cyanide for $1 \mathrm{hr}$, and the suspension was used for the next test.

An aliquot $(0.1 \mathrm{ml})$ of the cell suspension was added to $0.9 \mathrm{ml}$ of $50 \mathrm{mM}$ phosphate buffer $(\mathrm{pH} 6.5)$ at $30^{\circ} \mathrm{C}$ containing $50 \mathrm{mM}$ sucrose in a cell of polarographic apparatus (Oxygraph Type 8 of Central Science Co.). Potassium cyanide (final $0.5 \mathrm{mM}$ ) and SHAM (final 2 $\mathrm{mM}$ ) were added consecutively at a time interval during

Table 1 Test microbes and their sources.

\begin{tabular}{|c|c|}
\hline Test microbes & Sources \\
\hline Alternaria kikuchiana & Tottori University \\
\hline $\begin{array}{l}\text { Botrytis cinerea } \\
\text { Cochliobolus miyabeanus } \\
\text { Gibberella fujikuroi } \\
\text { Pythium sp. } \\
\text { Rhizoctonia solani } \\
\text { Valsa ceratosperma }\end{array}$ & The Institute of Physical and Chemical Research, RIKEN \\
\hline Monilinia fructicola & Nagano Prefrectural Agricultural Experiment Station \\
\hline $\begin{array}{l}\text { Pyricularia oryzae } \\
\text { Xanthomonas campestris pv. citri }\end{array}$ & $\begin{array}{l}\text { Isolates from the field in Yamaguchi prefecture collected by author's } \\
\text { laboratory }\end{array}$ \\
\hline Saccharomyces cerevisiae & Tokyo University of Agriculture \\
\hline
\end{tabular}


the course of oxygen consumption, which was recorded graphically by the apparatus.

\section{RESULTS}

\section{Joint Action of Respiration Inhibitors}

The synergism in fungitoxic action between an inhibitor of alternative pathway, SHAM, and inhibitors of
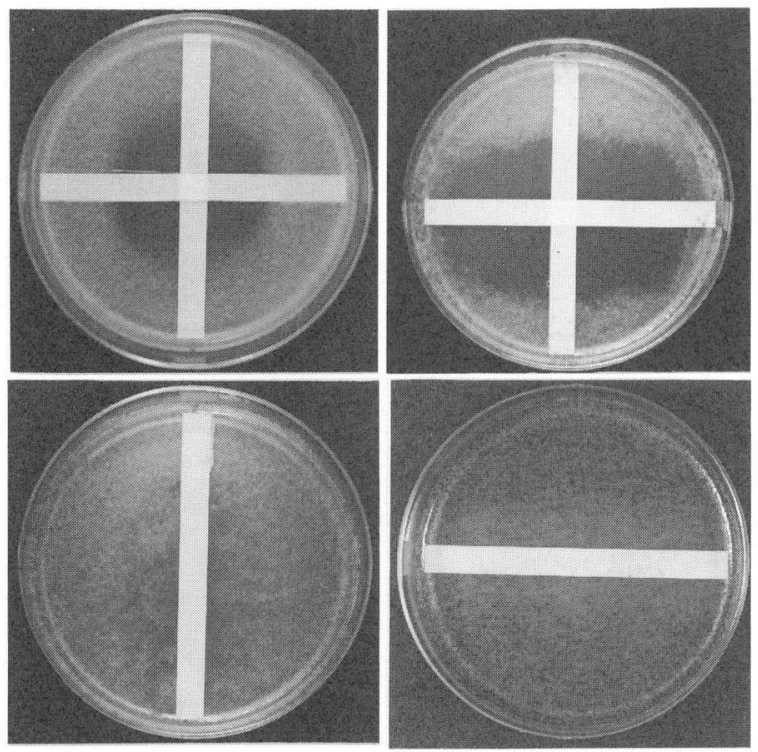

Fig. 3 Synergism in fungicidal action between methoxyacrylate I and SHAM in Botrytis cinerea (upper left) and Monilinia fructicola (upper right).

The vertical and horizontal paper stripes were impregnated with acetone solution of $\mathbf{I}(500 \mathrm{mg} / l)$ and of SHAM $(5 \mathrm{~g} / l)$ respectively. The antifungal activities of $\mathbf{I}$ alone (lower left) and SHAM alone (lower right) at the same dosages in M. fructicola are also shown for reference. cytochrome pathway, methoxyacrylate I, methoxyacrylate analogue II or antimycin A was observed in all the test phytopathogenic fungi, though it was less remarkable in G. fujikuroi, Pythium sp., $V$. ceratosperma. In $R$. solani, the synergism by SHAM with methoxyacrylates is remarkable but less with antimycin A. In $S$. cerevisiae and $X$. campestris pv. citri, there was no synergistic action. The results are summarized in Table 2. The synergism in fungitoxic action between methoxyacrylate $\mathbf{I}$ and SHAM in B. cinerea and M. fructicola are shown in Fig. 3.

\section{Oxygen Consumption in Phytopathogenic Fungi}

Oxygen consumption in $P$. oryzae without preincubation was $0.288 \mu \mathrm{mol} \mathrm{O} / \mathrm{min} / \mathrm{g}$ wet cell. By adding 0.5 $\mathrm{mM} \mathrm{KCN} \mathrm{(final)} \mathrm{this} \mathrm{respiration} \mathrm{was} \mathrm{inhibited} \mathrm{complete-}$ ly. Respiration activity in $P$. oryzae preincubated with $10 \mu \mathrm{M}$ methoxyacrylate I was $0.119 \mu \mathrm{mol} \mathrm{O}_{2} / \mathrm{min} / \mathrm{g}$ wet cell. This respiration was inhibited just slightly at 0.5 $\mathrm{mM} \mathrm{KCN}$ and the further addition of $2 \mathrm{mM}$ SHAM completely stopped the respiration. Oxygen consumption in $P$. oryzae preincubated with $1 \mathrm{mM} \mathrm{KCN} \mathrm{was}$ $0.169 \mu \mathrm{mol} \mathrm{O} \mathrm{O}_{2} / \mathrm{min} / \mathrm{g}$ wet cell and the respiration was slightly inhibited at $0.5 \mathrm{~mm} \mathrm{KCN}$. This respiration was completely inhibited by adding 2 mM SHAM. Similar results were obtained in the other phytopathogenic fungi, $B$. cinerea and $M$. fructicola. The respiration in $S$. cerevisiae preincubated with $10 \mu \mathrm{M}$ methoxyacrylate $\mathbf{I}$ or $1 \mathrm{mM} \mathrm{KCN}$ was completely inhibited at $0.5 \mathrm{mM} \mathrm{KCN}$. The data of $B$. cinerea, $M$. fructicola, $P$. oryzae and $S$. cerevisiae are described in Table 3 , and the records of oxygen consumption with $B$. cinerea and $S$. cerevisiae are shown in Fig. 4.

Table 2 Synergistic fungitoxic action of an inhibitor of the alternative pathway, SHAM, with inhibitors of cytochrome pathway, methoxyacrylate I, II or antimycin A.

\begin{tabular}{lccc}
\hline \multicolumn{1}{c}{ Test microbes } & \multicolumn{3}{c}{ Inhibitors of cytochrome pathway } \\
\cline { 2 - 4 } & Methoxyacrylate I & Methoxyacrylate II & Antimycin A \\
\hline Alternaria kikuchiana & + & \pm & \pm \\
Botrytis cinerea & ++ & + & ++ \\
Cochliobolus miyabeanus & ++ & \pm & ++ \\
Gibberella fujikuroi & + & + & + \\
Monilinia fructicola & ++ & + & + \\
Pyricularia oryzae & + & + & - \\
Pythium sp. & ++ & - & + \\
Rhizoctonia solani & \pm & - & - \\
Valsa ceratosperma & - & - & - \\
Saccharomyces cerevisiae & - &
\end{tabular}

Synergism in fungitoxic action observed by crossed paper technique between SHAM at $5 \mathrm{~g} / l$ of acetone solution used for impregnation of paper strips and inhibitors of cytochrome pathway at 20,100 and $500 \mathrm{mg} / l$ of acetone solution. Level of synergism is expressed by the dosage of inhibitors of cytochrome pathway which exhibit expansion of growth inhibitory zone at the intersection of test paper strips as follows : ++ , at $20 \mathrm{mg} / l ;+$, at $100 \mathrm{mg} / l ; \pm$, at $500 \mathrm{mg} / l ;-$, synergism was not observed at $500 \mathrm{mg} / \mathrm{l}$ of acetone solution. 
Table 3 Effects of respiration inhibitors on oxygen consumption in phytopathogenic fungi.

\begin{tabular}{|c|c|c|c|c|}
\hline \multirow{2}{*}{ Microbes } & \multirow{2}{*}{ Pretreated with } & \multirow{2}{*}{$\begin{array}{c}\mathrm{O}_{2} \text { consumption } \\
\left(\mu \mathrm{mol} \mathrm{O} \mathrm{O}_{2} / \mathrm{min} / \mathrm{g} \text { wet cell }\right)\end{array}$} & \multicolumn{2}{|c|}{ Inhibition (\%) by consecutive addition of } \\
\hline & & & $0.5 \mathrm{mM} \mathrm{KCN}$ & 2 mM SHAM \\
\hline \multirow{3}{*}{ Botrytis cinerea } & None & 0.397 & 92.1 & - \\
\hline & $10 \mu \mathrm{M}$ methoxyacrylate $\mathbf{I}$ & 0.066 & 4.8 & 100 \\
\hline & $1 \mathrm{mM} \mathrm{KCN}$ & 0.069 & 31.8 & 100 \\
\hline \multirow{3}{*}{ Monilinia fructicola } & None & 0.056 & 100 & - \\
\hline & $10 \mu \mathrm{M}$ methoxyacrylate $\mathbf{I}$ & 0.066 & 8.6 & 100 \\
\hline & $1 \mathrm{mM} \mathrm{KCN}$ & 0.047 & 35.1 & 100 \\
\hline \multirow{3}{*}{ Pyricularia oryzae } & None & 0.288 & 100 & - \\
\hline & $10 \mu \mathrm{M}$ methoxyacrylate $\mathbf{I}$ & 0.119 & 21.0 & 100 \\
\hline & $1 \mathrm{mM} \mathrm{KCN}$ & 0.169 & 31.5 & 100 \\
\hline \multirow{3}{*}{ Saccharomyces cerevisiae } & None & 0.522 & 100 & - \\
\hline & $10 \mu \mathrm{M}$ methoxyacrylate $\mathbf{I}$ & 0.047 & 100 & - \\
\hline & $1 \mathrm{~mm} \mathrm{KCN}$ & 0.025 & 100 & - \\
\hline
\end{tabular}
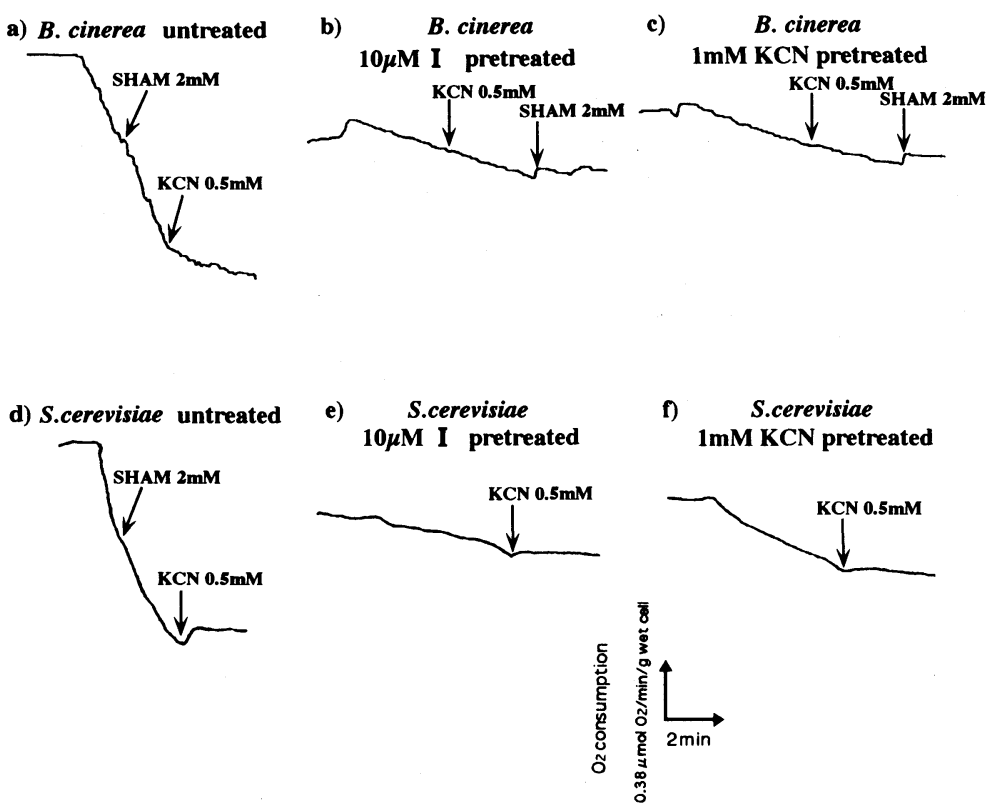

Fig. 4 The records of time course of oxygen consumption in Botrytis cinerea (a), B. cinerea pretreated with $10 \mu \mathrm{M}$ I (b), B. cinerea pretreated with $1 \mathrm{~mm} \mathrm{KCN} \mathrm{(c),} \mathrm{and} \mathrm{Saccharomyces} \mathrm{cerevisiae} \mathrm{(d),} \mathrm{S.} \mathrm{cerevisiae} \mathrm{pretreated} \mathrm{with} 10 \mu \mathrm{M} \mathrm{I} \mathrm{(e),} \mathrm{S.} \mathrm{cerevisiae}$ pretreated with $1 \mathrm{~mm} \mathrm{KCN} \mathrm{(f).}$

Arrows on the graphs indicate the time of addition of inhibitors.

\section{DISCUSSION}

A method was proposed to detect cyanide-insensitive pathway in fungal respiration. It is based on the joint fungitoxic action by the combination of an inhibitor of the alternative pathway, SHAM, with the inhibitors of cytochrome pathway. If the alternative pathway is not present in the test fungal cells, no joint action is expected between a set of the inhibitors. When the alternative pathway is formed in the fungal cells, joint inhibition of both the respiratory pathways is necessary for fungitoxicity. Therefore, inhibition of the fungal growth is exhibited only in the presence of both SHAM and a inhibitor of cytochrome pathway. This joint fungitoxicity is easily assayed by crossed paper technique. Since co-existence of both SHAM and an inhibitor of cytochrome pathway is expected only around the intersection of the two paper strips impregnated with the respective inhibitors, the growth-inhibitory zone must be remarkable only around the intersection.

This method was applied on various phytopathogenic fungi, because phytopathogenic fungi reported to exhibit the alternative respiratory pathway are rather limited. The result clearly suggested its existence in $B$. cinerea, $M$. 
fructicola and $P$. oryzae. The other test fungi also exhibited the similar joint fungitoxic action, but the synergism was less remarkable in some test fungi, such as G. fujikuroi, Pythium sp. and V. ceratosperma. In G. fujikuroi, Pythium sp. and $R$. solani, synergism of SHAM with methoxyacrylates was more or less observed but not with antimycin A. Thus antimycin A might be less active in induction of alternative pathway in these fungi. But none of the test phytopathogenic fungi seemed entirely lacking the alternative pathway. On the other hand, the yeast $S$. cerevisiae and the bacterium $X$. campestris pv. citri did not exhibit any synergism in joint antimicrobial activity between SHAM and inhibitors of cytochrome pathway under the condition of the present experiment. These results coincided with the effects of SHAM on the oxygen consumption of microbial cells with and without pretreatment with cytochrome inhibitors.

The induction of an alternative respiratory pathway in fungal cells may decrease the fungitoxicity of inhibitors of cytochrome pathway in respiratory chain. In fact, methoxyacrylate derivatives sometimes lack their fungitoxicity in in vitro tests. A methoxyacrylate analogue II was reported to be not necessarily a potent fungitoxicant in in vitro tests but it is effective to control rice blast because flavonoids in rice plants are inhibitors of the alternative respiratory pathway. And the joint inhibition of the analogue II and the flavonoids seemed the reason of the effectiveness. ${ }^{4)}$ The test for joint fungitoxic action of SHAM with another compounds may be a hopeful method to find the inhibitors of cytochrome respiratory pathway in phytopathogenic fungi.

In some plants, amounts of flavonoids are not necessarily enough to inhibit the alternative respiratory pathway. In such cases, combination of inhibitors of alternative pathway with methoxyacrylate fungicides might be effective to control plant diseases. Screening of such inhibitors may be conveniently conducted by the crossed paper technique.

Since cyanide-insensitive respiratory pathway was suggested to exist in a wide range of phytopathogenic fungi, it is an unavoidable factor to be investigated in the research on fungal respiration. Test methods using novel respiration inhibitors may be an useful tool in the investigation.

\section{REFERENCES}

1) J. L. Sherald \& H. D. Sisler : Plant Physiol. 46, 180 (1970)

2) J. L. Sherald \& H. D. Sisler : Plant Cell Physiol. 13, 1039 (1972)

3) E. Weiss-berg \& C. Tamm : Experientia 27, 778 (1971)

4) H. Yukioka, A. Mizutani, H. Tamura, N. Miki, M. Masuko \& R. Takeda : Abstr. ; Annu. Meet. Pestic. Sci. Soc. Jpn., p. 100,1994

5) A. Mizutani, H. Yukioka, H. Tamura, N. Miki, M. Masuko \& R. Takeda: Phytopathology 85, 306 (1995)

6) M. Watanabe, K. Hayashi, T. Tanaka \& Y. Uesugi : Proc. ; 11 th Int. Symp. Modern Fungicides and Antifungal Compounds, Reinhardsbrunn, Germany, pp. 111-115, 1995

7) M. Katagiri \& Y. Uesugi : Phytopathology 67, 1415 (1977)

8) H. Sugiura, K. Hayashi, T. Tanaka, M. Takenaka \& Y. Uesugi : Pestic. Sci. 39, 193 (1993)

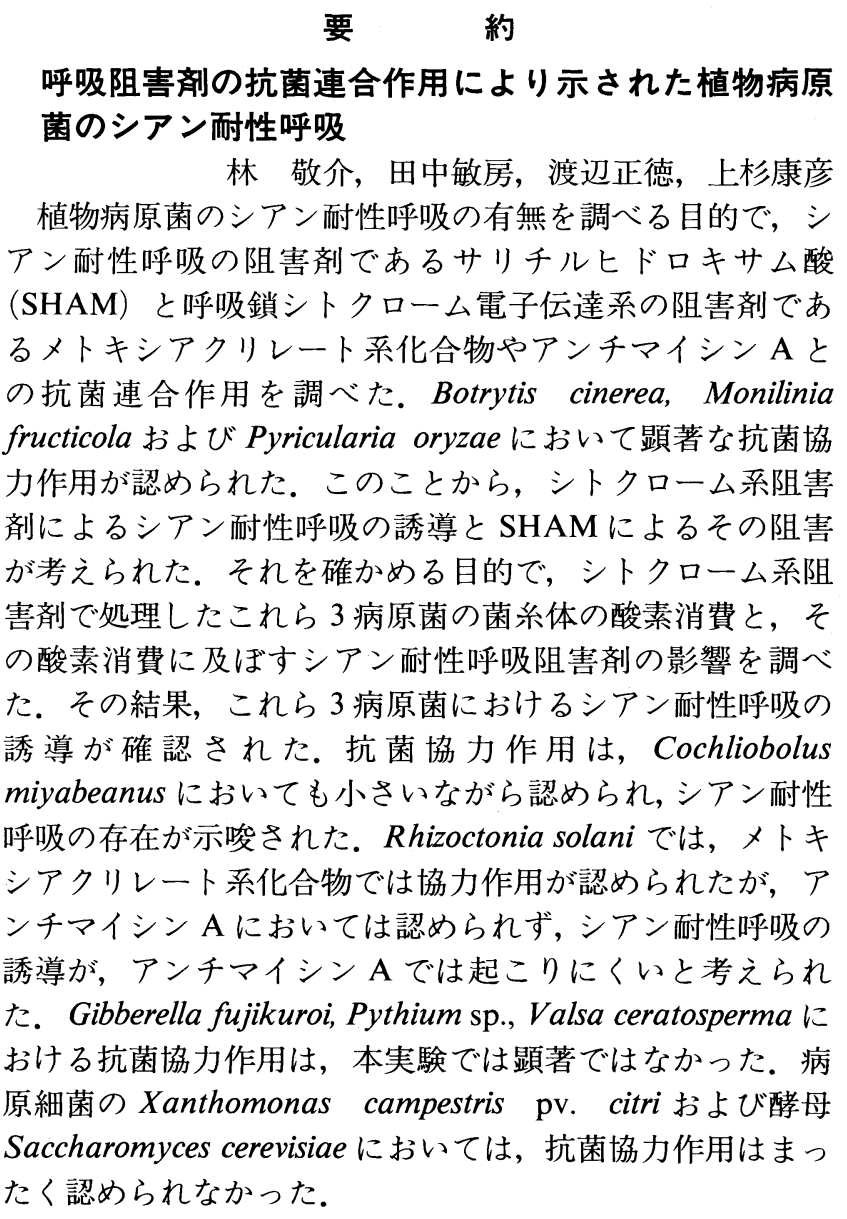
植物病原菌のシアン耐性呼吸の有無を調べる目的で，シ アン耐性呼吸の阻害剂であるサリチルヒドロキサム酸 (SHAM) と呼吸鎖シトクローム電子伝達系の阻害剤であ るメトキシアクリレート系化合物やアンチマイシン A と の抗菌連合作用を調べた. Botrytis cinerea, Monilinia fructicola および Pyricularia oryzaeにおいて顕著な抗菌協

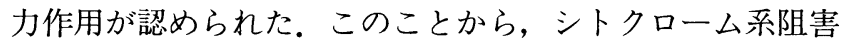
剂によるシアン耐性呼吸の誘導とSHAMによるその阻害 が考えられた。 それを確かめる目的で, シトクローム系阻 害剂で処理したこれら 3 病原菌の菌系体の酸素消費と, そ の酸素消費に及ぼすシアン耐性呼吸阻害剤の影響を調べ た.その結果，これら 3 病原菌におけるシアン耐性呼吸の 誘導が確認された。抗菌協力作用は, Cochliobolus miyabeanusにおいても小さいながら認められ, シアン耐性 呼吸の存在が示唆された. Rhizoctonia solani では, メトキ シアクリレート系化合物では協力作用が認められたが，ア ンチマイシン A においては認められず, シアン耐性呼吸の 誘導が，アンチマイシンA では起こりにくいと考之られ た. Gibberella fujikuroi, Pythium sp., Valsa ceratosperma に おける抗菌協力作用は, 本実験では顕著ではなかった。病 原細菌のXanthomonas campestris pv. citri および酵母 たく認められなかった。 